\title{
Civic Engagement on Global Issues: Participation and Attention in Indonesia's KitaAgni Movement
}

\author{
Alia Azmi ${ }^{1(*)}$, Nora Eka Putri ${ }^{1}$, and Ike Sylvia ${ }^{1}$

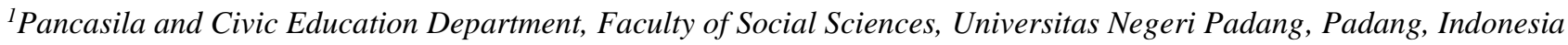

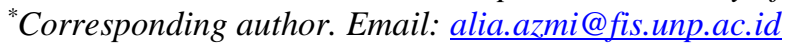

\begin{abstract}
In order to describe Indonesians' civic and political participation on global issues facilitated by the social media, particularly on anti-sexual harassment movements, this article analyzes students' activism on KitaAgni, a movement to propose anti-sexual harassment policy on campus. The KitaAgni movement was considered as one of the Indonesian versions of the global anti-sexual harassment movement MeToo. The research used qualitative and quantitative data to describe the activists' attention about the global anti-sexual harassment movement and their political participation on the issue. The indicators were adapted from the typology of political participation and civic engagement developed by Ekman and Amnå. The result shows that all respondents consider sexual harassment knowledge important, and the majority has attention on the global anti-sexual harassment movements. However, their political participation is more online than traditional. The small scope of the movement, although widely discussed in the media, shows that Indonesia's anti-sexual harassment movement has a long way to go. Further research could pursue a more effective way to foster movement that lead to improvement.
\end{abstract}

Keywords: Global movement, MeToo movement, KitaAgni movement, anti-sexual harassment movement, social media activism

\section{INTRODUCTION}

As our social lives are becoming more affected by the improvement of technology, civic engagement has changed in the global and digital era. Identified as individual and collective actions in the social and political life for a better society, civic engagement now consists of traditional (offline) activities and online engagement in the social networking sites. Research have developed from the debate about whether the internet is significant in influencing civic engagement (Dimitrova, Shehata, Strömbäck, \& Nord, 2011; Vissers, Hooghe, Dietlind, \& Mahéo, 2012) to accepting the new form of civic engagement and how it changed the practice of democracy (Smith, Schlozman, Verba, \& Brady, 2009; Farina, Epstein, Heidt, \& Newhart, 2014; Purdy, 2017). Civic activities have started to embrace the contribution of the digital media in sharing information, gather information, organize activities, and even as a public sphere to discuss ideas.

One of the forms of civic engagement in the political realm is the social movement. Cable (2017) defines social movement as the network individuals, groups, and/or organization who abridge around a shared purpose and identity to challenge and interact in their cause to achieve specific goals. As with other forms of civic engagement, social movement also took to the digital sphere to spread ideas, exchange information, organize mobs, and attract attention. The social media use for civic engagement also helps spread ideas across boundaries. Della Porta and Tarrow (2019) identifies this as the diffusion of ideas into the transnational context. Global movement is considered the pattern of $21^{\text {st }}$ century social activism.

However, digital interaction as civic engagement has become a debate among academicians. Some consider digital activism is less significant than the traditional ones (Lym, 2012), while others praise the contribution of the social media in the traditional civic engagement. Occupy Movement in 2012 in one of the examples where a movement can go global with the help of the internet. In late 2017, anti-sexual violence movement started by a Tweet in the United States and went viral across countries. The street protests in the US cities also reverberated in other big cities in other countries including Indonesia's.

Although researches about Indonesia's civic engagement are rich - as Indonesia has its own traditional term of "helping each other" such as "gotong royong" (Slikkerveer, 2019; Rosyani, Muchlis, Napitupulu, \& Faust, 2019) - there have been very few literatures about anti-sexual harassment movement, let alone the ones on campus. This article describes Indonesia's student movement KitaAgni that fights for the better policy on handling sexual harassment, to what extent the students' movement literacy inspires them and the forms of engagement they involved in. Agni is a pseudonym for a 
victim of sexual harassment in one of the top-ranked Indonesian universities Gadjah Mada University (UGM). The focus of the research take place in the overlapping fields of civic education, international relations, and media studies. Civic education is the home for discussion about civic engagement. However, there are very few discussions about civic engagement regarding the global issues. It is understandable that civic engagement mostly centered around the individual or groups involvement to solve society's problems, which are usually local and proximate to them. Civic education, although recognizing global citizenship, has not really connected local problems to the global ones. Meanwhile, in an increasingly interconnected world, it is very possible that events in one place are the indirect results of other events taking place somewhere else. International relations have been seeing the social movement in the transnational context, therefore understanding the global issues in local discussion and movement is quite familiar. Social movement, although mostly discussed in the field of sociology and political science, has been gradually recognized as an interdisciplinary study (Roggeband and Klandermans, 2017), such as in the field of communication due to the social media use in social movements.

\section{METHOD}

The research used descriptive qualitative and quantitative data and followed by interpretation of the data. We started by interviewing five students and one lecturer at the center of the movement to gather basic information about the movement. We also studied mainstream media news about the events. Since we were seeking online engagement, we used Google forms to collect quantitative data. We sent the forms link to 160 social media users (Instagram and Twitter) who responded (comment, like, or share) to any posts about the Agni case, particularly those who used the hashtag KitaAgni, and get 65 responses. We also sent the link to the informants and the women's crisis center organization Rifka Annisa who supported Agni and asked them to share the link in their Whatsapp group. The survey consisted of 11 rating items and open questions as well as multiple choice question to measure the activists' intensity in civic engagement, which indicators are adapted from those by Ekman and Amnå, who distinguish between manifest (formal political participation) and latent political participation (civic engagement and social involvement) (Ekman \& Amnå, 2012). The data were then described and interpreted qualitatively combined with the result of interviews and documentation studies.

\section{RESULTS AND DISCUSSION}

The KitaAgni Student Movement

The KitaAgni movement was dominantly initiated by the Faculty of Social and Political Science (FISIPOL) UGM students. The movement was the result of built-up dissatisfaction toward the university in handling sexual harassment reports in campus. In 2016, a FISIPOL lecturer was reported for sexual harassment, but the university, although deactivated him from the job, could not dismiss him from the position due to the complicated procedures to sanction a civil servant (Putsanra, 2019). Agni was also a student of FISIPOL. The Agni case was published in the Balairung press in November 5, 2018 (Maudy, 2018), at the time the Indonesian digital sphere had already been vibrant with the discussion on sexual harassment; the imprisonment of Baiq Nuril, a teacher who reported his boss for sexual harassment (Berita Hukum Kriminal CNN Indonesia, 2018), and the women movement's demand toward the legislatives to deliberate and approve the antisexual-violence bill (RUU PKS).

The report by Balairung was soon picked up by the mainstream media and the hashtag KitaAgni went viral in the social media. The activists, who had been involved in students' forum about sexual harassment on campus and wary about the lack of regulation and sanction against sexual predators, as well as dissatisfied with the university's response on the report, were quick to increase the scale to an offline petition and a protest march on November 8, 2018 (Kusuma, 2018). They collected thousands of autographs from students, lecturers, and staff. Dozens of activists marched to the rectorate, while others conducted discussions in almost all faculties in UGM to brief other students about the importance to support the issue.

In the public sphere, some digital versions of the mainstream media also used the hashtag KitaAgni, diffusing the viral posts to other regions in Indonesia. Some opinion pieces in the mainstream digital media discussed KitaAgni movement in relation with the global MeToo movement since it fought for almost similar cause: eradicating sexual harassment. However, the activists, Agni, and their supporters were disappointed by the ending of the case, where Agni decided to quit the litigation process and "choose other forms of struggle for justice", a statement translated by the university and the media as "the peaceful settlement". The decision was made because it became harder for Agni psychologically. However, the activists continue to demand for university's certain regulations to eradicate sexual harassment in campus. The university has been deliberating the regulation since then (Putsanra, Sosial Budaya Tirto, 2019). If it is finished and legalized, UGM will be the first campus in Indonesia to implement such regulation.

Participation and Attention in KitaAgni Movement

This research used indicators adapted from the typology of civic engagement and political participation by Ekman and Amnå. It includes indicators of not only the formal political participation (manifest participation) such as street protests, but also of less visible engagement such as the media use for gaining information (latent participation), even the citizen's disengagement (nonparticipation). This research developed questionnaire from the typology of manifest and latent participation only, which were considered suitable for the The KitaAgni movement that had happened online and offline. The adaptation resulted in 11 five-rating-scale questions for intensities, one three-rating-scale, and one multiple choices. 
The result shows that all respondents are the ones who consider knowledge about sexual harassment is important, as shown in their answers to the three-rating-scale (important, neutral, unimportant) question about their perceptions on the importance of the knowledge. It is understandable since the ones we requested to join the online survey are those who use KitaAgni hashtag. The respondents were also asked about their political engagement on the issue based on Ekman and Amnå's latent and manifest engagement: attention, action, and activism (Ekman \& Amnå, 2012). The respondents' attention indication can be seen from their abovementioned perception of the importance of the knowledge on sexual harassment, which all agreed as important.

The second form of engagement is actions, which were indicated from: (a) the interests in the news about sexual harassment cases and policymaking; (b) writing an opinion to a media about the issue; (c) donating money to women organizations; and (d) discussing on how to avoid and handle sexual harassment cases online or offline. The respondents were asked about their intensities in these actions using five-rating scales (always, often, sometimes, rarely, and never). Most of their responses fall in the higher categories: $30.8 \%$ always and $46.2 \%$ often follow the news; $15.4 \%$ always and $30.8 \%$ often involved in online discussion forums; $10.8 \%$ always and $23.1 \%$ often write an opinion to a media; $7.7 \%$ always and $24.6 \%$ often donate money to women organizations, and $30.8 \%$ always and $46.2 \%$ often discuss on how to avoid and handle sexual harassment cases online/offline. The numbers show that the actions intensities were higher in interests in the news, online involvement in discussion forums and online/offline discussions on sexual harassment.

The third engagement, activism, were indicated from: (a) involvements in social movements or forums; (b) demonstrating in strikes or street protests. The responses on involvements in social movements or forums about handling sexual harassment is $18.5 \%$ always and $20 \%$ often. For political activism, we allow respondents to choose multiple forms of engagement in the KitaAgni case, which include online and offline activism. Their responses show that $64.6 \%$ liked or shared a post or a comment about the Agni case at the social media, 52.3\% commented on a social media post, $46.2 \%$ posted their selfies that wrote supports for the movement, $26.2 \%$ joined the students' march and protest, and $58.5 \%$ invited friends and families to support the movement online and offline. It can be concluded that online participation was much higher that the traditional participation, and it is compatible with the finding that a big majority of respondents found out about the case from the social media $(83.1 \%)$.

Activism were also measured by their attention to the global anti-sexual harassment movement. The intensity of reading news about global anti-sexual violence movement is slightly lower than the news about KitaAgni case; $12.3 \%$ respondents always and $36.5 \%$ always follow the news about the global MeToo movement, while $29.2 \%$ always and $30.8 \%$ often follow the news about the International
Women's Day. However, the majority of $52.3 \%$ never participated in the Women's March, an annual protest to stop violence against women and vulnerable groups.

The findings suggest that most of the respondents have the highest intensities of engagement in the social media to share, like, and comment, as well as to discuss the problem online. However, participation in the actual protest is significantly lower. This might due to the lack of other centers of the movement outside of UGM, while the respondents are from various regions across Indonesia. Several students of the University of Indonesia-located in the capital province Greater Jakarta-were reported to stage a protest and post the picture in the social media. This approves Lym (2012)'s argument about the lack of real movement beside clicktivism in Indonesia. In the KitaAgni case, traditional activism was present, since the activists believe that mere online activism would not result in greater change such as the making of the regulation. Those activists, which were predominantly from the FISIPOL, were possibly a very different group from the ones who engaged in the social media. However, according to Ekman and Amnå (2012), this higher level of latent forms of political participation means that we need to better understand the new forms of political participation as well as the participation in various countries. Indonesia, as a developing country, still has dominant hidden political participation.

Another aspect is the average level of attention about the global issue. Global issues, particularly the anti-sexualharassment movement, is still seen as Western feminist influence, in addition to the already marginal concern on struggle against sexual harassment. Although Witoszek (2014) addresses the importance of global citizenship, she argues that the best thing to introduce global activism is by addressing the issues in the local level. The global antisexual harassment movement has been going on in the 2010s particularly with the help of the social media. The MeToo movement was started in the United States in 2017 by Hollywood actresses. It has been viral worldwide ever since, prompting victims of sexual harassment to share their experience in the social media using the MeToo hashtag. However, MeToo is not exclusively American or Western, nor it is the only anti-sexual harassment movement. Other countries have their own struggles against sexual harassment, for example, India started its own anti-sexual violence movement in 2013 after the gang rape of a student that lead to her death (BBC, 2017). Indonesian activists started the social media \#MulaiBicara (literally means "start speaking up") hashtag in 2016 to demand the legalization of the nation's anti-sexual violence bill RUU PKS. The limited movement in Indonesia is considered as the result of the patriarchal culture (Arendra, 2017).

The KitaAgni student activists were dominantly from the FISIPOL social and political science faculty, therefore they already had courses that discuss about sexual harassment in gender studies-related courses in most social humanity studies, which include materials on global problems in the fields of human rights, law, psychology, and politics. Among the 65 respondents, only 18 who did 
not come from the social humanity fields. The lower level attention to the issue were also addressed by the activists, stating that students from the social humanity fields were more aware of the sexual harassment problems thanks to the formal courses' material in class and informal discussion forums around campus.

\section{CONCLUSIONS}

The movement shows that online and offline activism can no longer be separated. Online information about the movement can spread the news well and inform other people outside of the region, even though the issue was quite local. Offline activism is still important to push changes particularly when demanding policymaking and changes. The KitaAgni movement has not yet resulted in anti-sexual harassment regulation by the university, and the activists didn't consider the movement successful, but it contributed in the discussion about sexual harassment in the country, which still does not have a particular antisexual harassment regulation nationally, regionally, and institutionally. The research shows that online activism is strong, including not only students from UGM and Yogyakarta universities, but also students and alumni of other universities. Most activists and supporters of KitaAgni have interests on sexual harassment knowledge and have a significant engagement on the issue, but very few involved in traditional participation of street protests. Similar movement should continue, since sexual harassment cases are still handled terribly in Indonesia, but the social media can help deliver the voices of the marginal. Further research can examine an effective way to foster civic engagement both online and offline to encourage better solution to sexual harassment in Indonesia, particularly in campus.

\section{ACKNOWLEDGMENTS}

The authors would like to thank Universitas Negeri Padang for funding the research.

\section{REFERENCES}

[1] Arendra, E. (2017). GlobeAsia. Retrieved January 3, 2019, from https://www.globeasia.com/columnists/metoopaternalistic-indonesia/

[2] BBC. (2017). BBC News. Retrieved March 6, 2019, from https://www.bbc.com/news/worldasia-india-42236752

[3] Berita Hukum Kriminal CNN Indonesia. (2018, November 14). Retrieved from CNN Indonesia: https://www.cnnindonesia.com/nasional/20181114 133306-12-346485/kronologi-kasus-baiq-nurilbermula-dari-percakapan-telepon

[4] Della Porta, D., \& Tarrow, S. (2019). Transnational Protest and Global Activism. Lanham: Rowman \& Littlefield Publishers, Inc.

[5] Dimitrova, D. V., Shehata, A., Strömbäck, J., \& Nord, L. W. (2011). The Effects of Digital Media on Political Knowledge and Participation in
Election Campaigns: Evidence From Panel Data. Communication Research, XX(X), 1-24. doi:10.1177/0093650211426004

[6] Ekman, J., \& Amnå, E. (2012). Political Participation and Civic Engagement: Towards a New Typology. Human Affairs, 22, 283-300. doi:10.2478/s13374-012-0024-1

[7] Farina, C. R., Epstein, D., Heidt, J., \& Newhart, M. J. (2014). Designing an Online Civic Engagement Platform: Balancing More vs. Better Participation in Complex Public Policymaking. International Journal of E-politics, 5(1), 16-40. Retrieved $11 \quad 25, \quad 2019, \quad$ from http://scholarship.law.cornell.edu/cgi/viewcontent. cgi article $=2524 \&$ context $=$ facpub

[8] Kusuma, W. (2018, November 14). Kompas Regional. (A. Ika, Editor) Retrieved September 12, 2019, from Kompas: https://regional.kompas.com/read/2018/11/14/132 34761/kasus-dugaan-pelecehan-seksualmahasiswi-ugm-saat-kkn-viral-lewat?page=all

[9] Lym, M. (2012). Many Clicks but Little Sticks, Social Media Activism in Indonesia. Digital Activism in Asia Reader, 127-154.

[10] Maudy, C. (2018, November 5). Balairung Press Laporan Utama. Retrieved from Balairung Press: http://www.balairungpress.com/2018/11/nalarpincang-ugm-atas-kasus-perkosaan/

[11] Purdy, S. J. (2017). Internet use and civic engagement. Computers in Human Behavior, 71, 318-326. Retrieved 11 25, 2019, from https://sciencedirect.com/science/article/pii/s0747 563217300845

[12]Putsanra, D. V. (2019, May 29). Sosial Budaya Tirto. Retrieved from tirto.id: https://tirto.id/ugmsusun-peraturan-pencegahan-dan-penanganankekerasan-seksual-d9gE

[13] Putsanra, D. V. (2019, Maret 14). Tirto/Pendidikan. Retrieved from tirto.id: https://tirto.id/eh-agni-dan-ugm-yang-tak-tegasmenangani-kasus-kekerasan-seksual-dju2

[14] Rosyani, R., Muchlis, F., Napitupulu, D., \& Faust, H. (2019). Gotong royong (cooperation) transformation of rural communities in Jambi Province, Indonesia. Retrieved 11 25, 2019, from https://onlinejournal.unja.ac.id/jes/article/view/7466

[15] Slikkerveer, L. J. (2019). Gotong Royong: An Indigenous Institution of Communality and Mutual Assistance in Indonesia. Retrieved 11 25, 2019 ,

from https://link.springer.com/chapter/10.1007/978-3030-05423-6_14

[16] Smith, A., Schlozman, K. L., Verba, S., \& Brady, H. E. (2009). The internet and civic engagement. Retrieved $11 \quad 25, \quad 2019, \quad$ from 
https://ictlogy.net/bibliography/reports/projects.ph $\mathrm{p}$ ?idp $=2273$

[17] Vissers, S., Hooghe, M., Dietlind, S., \& Mahéo, V.-A. (2012). The Impact of Mobilization Media on Off-Line and Online Participation: Are Mobilization Effects Medium-Specific? Social Science Computer Review, 30(2), 152-169. doi:10.1177/0894439310396485

[18] Witoszek, N. (2014). The Idea of Global Citizenship in the Age of Ecomodernity. In A. B. Sterri, Global Citizen--Challenges and Responsibility in an Interconnected World (pp. 61-69). Rotterdam: Sense Publishers. 